Situs Jurnal : $\underline{\text { http://ejurnal.stiepancasetia.ac.id/index.php/jieb }}$

Jilid 5 Nomor 1 Maret 2019

Hal $037-051$

\title{
ANALISIS TINGKAT KESEHATAN BANK UMUM SYARIAH BERDASARKAN METODE RGEC RISK PROFILE, GOOD CORPORATE GOVERNANCE, EARNINGS, AND CAPITAL PADA PT. BANK MUAMALAT INDONESIA
}

\section{Jumriaty Jusman*}

Abstract: This research was conducted on the basis of observations of events that occurred at PT. Bank Muamalat Indonesia, where the bank is spread, issues will experience liquidity. So the purpose of this study is to determine the health level of PT. Bank Muamalat Indonesia using the RGEC method (risk profile, good corporate governance, earnings and capital) for the 20152017 period. This research will be conducted by collecting data in accordance with the provisions stipulated in Bank Indonesia regulations No.13 / 1 / PBI / 2011 and SE No.13 / 24 / DPNP. The research subject in this study was PT Bank Muamalat Indonesia, Tbk. The object of this research is the financial statements and publications of PT Bank Muamalat Indonesia, Tbk 2015-2017 period. The results of the study showed that the health level of Bank Muamalat Indonesia using RGEC showed the predicate of bank health in accordance with the standards set by Bank Indonesia, with the results of financial ratios obtained from annual reports adjusted to the RGEC Component Ranking Criteria Matrix (Risk Profile, Good Corporate Governance, Earning and Capital) and the calculation of the final composite value on average $60 \%$, it can be concluded that PT. Bank Muamalat Indonesia in 2015-2017 ranked 4 (four) with the title "LESS HEALTH".

\section{Keywords: Bank soundness, RGEC}

Abstrak: Penelitian ini dilakukan atas dasar pengamatan terhadap peristiwa yang terjadi pada PT. Bank Muamalat Indonesia, dimana bank tersebut tersebar isu akan mengalami likuiditas. Maka tujuan penelitian ini untuk mengetahui tingkat kesehatan PT. Bank Muamalat Indonesia dengan menggunakan metode RGEC (risk profile, good corporate governance, earnings and capital) periode 2015-2017. Penelitian ini akan dilakukan dengan mengumpulkan data- data sesuai dengan ketentuan yang telah diatur dalam peraturan Bank Indonesia No.13/1/PBI/2011 dan SE No.13/24/DPNP. Subjek penelitian dalam penelitian ini adalah PT Bank Muamalat Indonesia,Tbk. Objek penelitian ini adalah laporan keuangan dan tata kelolah publikasi PT Bank Muamalat Indonesia,Tbk Periode 2015-2017. Hasil penelitian bahwa tingkat Kesehatan Bank Muamalat Indonesia dengan menggunakan RGEC yang menunjukkan predikat kesehatan bank sesuai dengan standar yang telah ditetapkan oleh Bank Indonesia, dengan hasil rasio keuangan yang diperoleh dari laporan tahunan kemudian disesuaikan dengan Matriks Kriteria Peringkat Komponen RGEC (Risk Profile, Good Corporate Governance, Earning dan Capital) dan perhitungan nilai komposit akhir rata-rata 60\% maka dapat disimpulkan bahwa PT. Bank Muamalat Indonesia pada tahun 2015 -2017 memperoleh peringkat 4 (empat) dengan predikat "KURANG SEHAT"

Kata kunci : Tingkat kesehatan Bank, RGEC. 


\section{Latar Belakang}

Sistem keuangan yang stabil berperan dalam membantu pertumbuhan ekonomi nasional sebagai mana tercantum dalam Arsitektur Perbankan Indonesia (API). Kestabilan sistem keuangan mencerminkan Sistem perbankan yang sehat. Pemeliharaan kesehatan bank salah satunya dilakukan dengan tetap menjaga likuiditas sehingga bank dapat memenuhi kewajibannya dan menjaga kinerjanya agar bank selalu memperoleh kepercayaan dari masyarakat (Arifin, Lasta dkk. 2014). Penilaian tingkat kesehatan bank menjadi sarana bagi Bank umum konvensional maupun bank umum syariah dalam melakukan evaluasi terhadap kondisi bank maupun permasalahan-permasalahan yang dihadapi oleh bank. Kesehatan bank menjadi perhatian Bank Indonesia selaku bank sentral di Indonesia yang berkewajiban untuk mengawasi bank, baik bank konvensional maupun bank syariah dalam menjalankan kegiatan usahanya di Indonesia. Berdasarkan Peraturan Bank Indonesia (PBI) No.13/1/PBI/2011 tentang Penilaian Tingkat Kesehatan Bank Umum. Maka sejak Januari 2012 seluruh Bank Umum di Indonesia sudah harus menggunakan pedoman penilaian tingkat kesehatan bank dengan tata cara terbaru yaitu Metode RGEC, yaitu singkatan dari Risk Profile, Good Corporate Governance, Earning, dan Capital. Dimana fungsi, tugas dan wewenang pengaturan dan pengawasan kesehatan bank beralih dari Bank Indonesia ke Otoritas Jasa Keuangan (OJK) (Booklet Perbankan Indonesia, 2014). Otoritas Jasa Keuangan (OJK) saat ini masih mengadopsi dan menerapkan RGEC berdasarkan Peraturan Bank Indonesia (PBI) No.13/1/PBI/2011 tentang Penilaian Tingkat Kesehatan Bank Umum dan Surat Edaran (SE) No. 13/24/DPNP tentang petunjuk pelaksanaan PBI No. 13/1/PBI/2011.

Disektor keuangan, perbankan Islam telah lama berperan dalam menggerakkan perekonomian, baik secara global maupun untuk perekonomian indonesia. Perbankan Syariah di Indonesia baru mulai beroperasi sejak dikeluarkannya Undang-undang No.7 Tahun 1992, tentang perbankan. Dalam undang-undang tersebut salah satu pasalnya memungkinkan untuk memberi peluang untuk bank menyalurkan kreditnya berdasarkan bagi hasil. Sejak awal Bank Indonesia sebagai otoritas yang berkewajiban mengembangkan dan mengatur industri perbankan Syariah, mengambil inisiatif aktif untuk ikut mengembangkan industri ini. Bank indonesia melihat industri ini memiliki potensi yang besar untuk berkontribusi dalam menciptakan sistem keuangan nasional yang stabil dan kemudian dapat memberikan manfaat bagi perekonomian Indonesia. Fakta ini sudah menjadi catatan sejarah dimana perbankan syariah pada beberapa periode krisis baik yang terjadi di Indonesia maupun di tingkat global, dapat bertahan dan tetap mempertahankan pertumbuhan yang relatif tinggi (Agus D.W Martowardojo, 2016).

Bank Muamalat Indonesia adalah bank syariah pertama dan satu satunya yang memiliki cabang penuh di luar negeri. Sebagai pelopor industri perbankan syariah di Indonesia, Bank Muamalat Indonesia senantiasa meningkatkan performa bisnisnya melalui layanan prima di seluruh jaringan usaha serta mengembangkan produk dan jasa yang mampu mengakomodir kebutuhan nasabah baik perorangan maupun korporasi. Bank Muamalat Indonesia terus bergerak secara agresif dalam upaya menggapai pertumbuhan keuangan syariah di Indonesia (Laporan tahunan Bank Muamalat Indonesia,2017). Citra dewi (2007) melakukan penelitian penilaian tingkat kesehatan bank umum syariah dan unit usaha syariah dengan analisis camel dengan salah satu studi kasus Bank Muamalat indonesia tahun 2002-2005, hasil analisis disimpulkan bahwa Tingkat kesehatan Bank Muamalat Indonesia,Tbk tahun 2002-2005 berada peringkat 2 dimana bank tergolong sangat baik dan mampu mengatasi seluruh pengaruh negatif kondisi perekonomian dan industri keuangan, namun bank memiliki kelemahan yang dapat diatasi oleh tindakan rutin. Penelitian terdahulu juga dilakukan oleh Pandy Pramadie dkk, dengan judul "analisis penilaian tingkat kesehatan pada bank Muamalat Indonesia,Tbk periode 
2010-2012 dengan menggunakan metode CAMEL" dengan hasil kajian menunjukkan bahwa hasil perhitungan Analisa CAMEL dapat dikatakan PT Bank Muamalat Indonesia, Tbk tahun 2010-2012 Sehat. Hal ini menunjukkan bahwa PT Bank Muamalat Indonesia, Tbk tahun 20102012 telah mampu mengelola dana dari masyarakat Kaltim guna ikut dalam pembangunan daerah.

Namun pada tahun 2017 PT Bank Muamalat Indonesia dalam beberapa bulan terakhir santer pemberitaan media massa dikabarkan bangkrut. Pada TRIBUN-MEDAN.com, MEDAN-Bank Muamalat dikabarkan akan menutup tujuh Kantor Cabang Pembantu (KCP) di sumatera Utara. Data yang diterima www.tribun medan.com, KCP Muamalat Perdagangan, Indrapura, Katamso, Pakam dan Aek Kanopan terakhir pada Jumat (21/10/2016) lalu. Akan tetapi berita itu di tepis oleh Ma'ruf selaku Ketua Dewan Pengawas Syariah Bank Muamalat juga menegaskan, saat ini, BMI dalam kondisi sehat. Oleh karena itu, ia menyayangkan ada pihak-pihak yang melontarkan wacana negatif terkait kondisi keuangan bank syariah pertama di Indonesia (CNN Indonesia, Rabu 28/02/2018).

Dengan melihat masalah tersebut dan ingin memastikan sendiri, maka peneliti tertarik untuk menganalisis kesehatan Bank Muamalat Indonesia yang akan dituangkan dalam bentuk karya tulis ilmiah dengan judul "Analisis Tingkat Kesehatan Bank Umum Syariah Berdasarkan Metode RGEC (Risk Profile, Good Corporate Governance, Earnings, and Capital) pada PT. Bank Muamalat Indonesia,Tbk .

Berdasarkan uraian di atas, maka permasalahan dalam penelitian ini adalah bagaimana analisis tingkat kesehatan PT. Bank Muamalat Indonesia,Tbk dengan menggunakan metode RGEC (Risk Profile, Good Corporate Governance, earnings, and Capital) periode 2015-2017 dan juga penelitian ini bertujuan untuk mengetahui dan memahami analisis tingkat kesehatan PT. bank Muamalat Indonesia,Tbk dengan metode RGEC periode 2015-2017.

\section{Kajian Literatur}

Menurut Kasmir (2007:41) tingkat kesehatan bank adalah kemampuan suatu bank untuk melakukan kegiatan operasional perbankan secara normal dan mampu memenuhi kewajibannya dengan baik dengan cara-cara yang sesuai dengan peraturan perbankan yang berlaku. Berdasarkan pasal 29 UU No. 7 tahun 1992 sebagaimana telah diubah dengan UU No. 10 tahun 1998 tentang perbankan, bank wajib memelihara tingkat kesehatannya sesuai dengan ketentuan kecukupan modal, kualitas aset, kualitas manajemen, likuiditas, rentabilitas dan solvabilitas, serta aspek lain yang berkaitan dengan usaha bank dan wajib melakukan kegiatan usaha sesuai dengan prinsip kehati-hatian. Berdasarkan POJK No.4/POJK.03/2016 tentang Penilaian Tingkat Kesehatan Bank Umum dan POJK No.8/POJK.03/2014 tentang Penilaian Tingkat Kesehatan Bank Umum Syariah dan Unit Usaha Syariah, bank wajib melakukan penilaian tingkat kesehatan bank dengan menggunakan pendekatan rasio (risk-based banking rating) baik secara individu maupun konsolidasi dengan mencakup beberapa faktor diantaranya yaitu: profil risiko, good corporate governance, rentabilitas dan permodalan .Penilaian tingkat kesehatan bank dengan menggunakan pendekatan resiko dilakukan berdasarkan analisis yang komperhensif terhadap 4 aspek yaitu risk profile, governance, earning dan capital yang biasanya disingkat RGEC. 
Tabel 1. Kriteria Tingkat Kesehatan Bank Dengan Metode RGEC

\begin{tabular}{lll}
\hline Bobot & Peringkat komposit & Keterangan \\
\hline $86 \%-100 \%$ & Peringkat komposit 1 & Sangat sehat \\
\hline $71 \%-85 \%$ & Peringkat komposit 2 & Sehat \\
\hline $61 \%-70 \%$ & Peringkat komposit 3 & Cukup sehat \\
\hline $41 \%-60 \%$ & Peringkat komposit 4 & Kurang sehat \\
\hline$\leq 40 \%$ & Peringkat komposit 5 & Tidak sehat \\
\hline
\end{tabular}

Sumber : Bank Indonesia

Berdasarkan Peraturan Bank Indonesia Pasal 9 No.13/ 1/ PBI/ 2011 peringkat setiap faktor yang ditetapkan Peringkat Komposit (composite rating), sebagai berikut :

1. Peringkat Komposit 1 (PK-1), mencerminkan kondisi bank yang secara umum sangat sehat, sehingga dinilai sangat mampu menghadapi pengaruh negatif yang signifikan dari perubahan kondisi bisnis dan faktor eksternal lainnya.

2. Peringkat Komposit 2 (PK-2), mencerminkan kondisi bank yang secara umum sehat, sehingga dinilai mampu menghadapi pengaruh negatif yang signifikan dari perubahan kondisi bisnis dan faktor eksternal lainnya.

3. Peringkat Komposit 3 (PK-3), mencerminkan kondisi bank yang secara umum cukup sehat, sehingga dinilai cukup mampu menghadapi pengaruh negatif yang signifikan dari perubahan kondisi bisnis dan faktor eksternal lainnya.

4. Peringkat Komposit 4 (PK-4), mencerminkan kondisi bank yang secara umum kurang sehat, sehingga dinilai kurang mampu menghadapi pengaruh negatif yang signifikan dari perubahan kondisi bisnis dan faktor eksternal lainnya.

5. Peringkat Komposit 5 (PK-5), mencerminkan kondisi bank yang secara umum tidak sehat, sehingga dinilai tidak mampu menghadapi pengaruh negatif yang signifikan dari perubahan kondisi bisnis dan faktor eksternal lainnya.

Dalam menentukan penilaian tingkat kesehatan bank, sudah ditentukan oleh Bank Indonesia yang kini beralih tanggung jawab kepada OJK. Berdasarkan Peraturan Bank Indonesia No. 13/ 1/ PBI/ 2011 dan SE No. 13/ 24/ DPNP tanggal 25 Oktober 2011 tentang Sistem Penilaian Tingkat Kesehatan Bank dengan menggunakan pendekatan resiko (Risk-based Bank Rating) baik secara individual maupun secara konsolidasi. Tata cara penilaian ini lebih sering dikenal dengan metode RGEC yaitu singkatan dari Risk Profile (Profil resiko), Good Corporate Governance (GCG), Earning (rentabilitas), dan Capital (permodalan). Adapun penjelasan dari komponen-komponen metode RGEC adalah sebagai berikut :

1. Risk Profile

Penilaian faktor profil resiko merupakan penilaian terhadap resiko inhern dan kualitas pennerapan manajemen risiko dalam aktivitas operasional bank. Penelitian ini hanya akan menggunakan dua penilaian risiko yaitu :

a. risiko pembiayaan merupakan suatu resiko akibat kegagalan atau ketidakmampuan nasabah dalam mengembalikan pinjaman/pembiayaan yang diterima bank sesuai dengan jangka waktu yang ditentukan atau dijadwalkan. Semakin besar rasio NPF yang dimiliki oleh bank maka semakin banyak pembiayaan bermasalah yang terjadi. Hal tersebut disebabkan oleh beberapa faktor Intern dan Ekstern . Resiko pembiayaan dihitung dengan menggunakan rasio Non Performing Financing (NPF). 
$N P L=\frac{\text { pembiayaan bermasalah }(\mathrm{KL}, \mathrm{D}, \mathrm{M})}{\text { total pembiayaan }} \times 100 \%$

Tabel 2. Matriks Kriteria Penetapan Peringkat Profil Risiko (NPF)

\begin{tabular}{lll}
\hline Peringkat & Keterangan & Kriteria \\
\hline 1 & Sangat sehat & NPF $\leq 2 \%$ \\
\hline 2 & Sehat & $2 \%-5 \%$ \\
\hline 3 & Cuup sehat & $5 \%-8 \%$ \\
\hline 4 & Kurang sehat & $8 \%-12 \%$ \\
\hline 5 & Tidak sehat & $\mathrm{NPF} \geq 12 \%$ \\
\hline
\end{tabular}

Sumber : SE BI No.13/24/DPNP tahun 2011

b. risiko likuiditas merupakan rasio yang digunakan untuk mengukur kemampuan bank dalam memenuhi kewajiban jangka pendeknya pada saat ditagih. Semakin tinggi rasio FDR memberikan indikasi rendahnya likuiditas bank, karena dana bank lebih banyak digunakan untuk memberikan pembiayaan dari pada diinvestasikan dalam bentuk kas. Risiko likuiditas dihitung dengan menggunkan rasio Financing to Deposit Ratio (FDR).

$$
F D R=\frac{\text { total pembiayaan }}{\text { total dana pihak ketiga }} \times 100 \%
$$

Tabel 3. Matriks Kriteria Penetapan Peringkat Profil Risiko (FDR)

\begin{tabular}{lll}
\hline Peringkat & Keterangan & Kriteria \\
\hline 1 & Sangat sehat & FDR $\leq 75 \%$ \\
\hline 2 & Sehat & $75 \%-85 \%$ \\
\hline 3 & Cukup sehat & $85 \%-100 \%$ \\
\hline 5 & Kurang sehat & $100 \%-120 \%$ \\
\hline
\end{tabular}

Sumber : SE BI No.6/23/DPNP Tahun 2004

2. Good Corporate Governance

Good Corporate Governance adadalah suatu tata kelola bank syariah yang menerapkan prinsip-prinsip keterbukaan (transparansi), akuntabilitas (accountability), pertanggungjawaban (responsibility), profesional (professional), dan kewajaran (fairness) (Rianto, 2013). Bank wajib melakukan self assesment atas pelaksanaan GCG minimal satu kali dalam setahun. Self assessment menggunkan kertas kerja self assessment. Adapun kriteria peringkat adalah sebagai berikut :

a. Peringkat 1 : hasil analisis self assessment menunjukkan bahwa pelaksanaan GCG bank sangat sesuai dengan kriteria/indikator.

b. Peringkat 2 : hasil analisis self assessment menunjukkan bahwa pelaksanaan GCG bank sesuai dengan kriteria/indikator.

c. Peringkat 3 : hasil analisis self assessment menunjukkan bahwa pelaksanaan GCG bank cukup sesuai dengan kriteria/indikator.

d. Peringkat 4 : hasil analisis self assessment menunjukkan bahwa pelaksanaan GCG bank kurang sesuai dengan kriteria/indikator. 
e. Peringkat 5 : hasil analisis self assessment menunjukkan bahwa pelaksanaan GCG bank tidak sesuai dengan kriteria/indikator.

Tabel 4. Matriks peringkat faktor good corporate governance (GCG)

\begin{tabular}{lll}
\hline Peringkat & Nilai komposit & Predikat \\
\hline 1 & $\leq 1,5$ & sangat baik \\
\hline 2 & $1,5-2,5$ & Baik \\
\hline 3 & $2,5-3,5$ & Cukup baik \\
\hline 4 & $3,5-4,5$ & Kurang baik \\
\hline 5 & $4,5-5$ & Tidak baik \\
\hline
\end{tabular}

Sumber : Bank Indonesia

3. Earning (Rentabilitas)

Penilaian rentabilitas dimaksudkan untuk menilai kemampuan bank dalam menghasilkan laba. Penilaian kuantitatif faktor rentabilitas dilakukan dengan melakukan penilaian terhadap komponen- komponen sebagai berikut:

a. Return on assets (ROA)

Return on assets merupakan rasio yang digunakan untuk mengukur keberhasilan manajemen dalam menghasilkan laba. Semakin tinggi persentase berarati tingkat produktivitas akan semakin meningkat. Rasio ROA dirumuskan sebagai berikut:

$$
R O A=\frac{\text { Laba sebelum pajak }}{\text { Total Asset }} \times 100 \%
$$

Tabel 5. Matriks kriteria penetapan peringkat ROA

\begin{tabular}{lll}
\hline Peringkat & Keterangan & Kriteria \\
\hline 1 & Sangat sehat & $\mathrm{ROA} \geq 1,5 \%$ \\
\hline 2 & sehat & $1,25 \% 1,5 \%$ \\
\hline 3 & Cukup sehat & $0,5 \% 1,25 \%$ \\
\hline 4 & Kurang sehat & $0 \%-0,5 \%$ \\
\hline 5 & Tidak sehat & $\leq 0 \%$ \\
\hline
\end{tabular}

Sumber : SE BI No.13/24/DPNP tahun 2011

b. Return On Equity (ROE)

Return On Equity (ROE) merupakan rasio untuk mengukur kemampuan bank dalam memperoleh keuntungan bersih dikaitkan dengan pembayaran deviden. Semakin tinggi persentase ROE yang diperoleh maka semakin besar kenaikan laba bersih yang diperoleh oleh bank, begitupun sebaliknya semakin rendah persentase ROE maka semakin kecil laba bersih yang diterima oleh bank. Rasio ini dirumuskan dengan :

$$
R O E=\frac{\text { Laba setelah pajak }}{\text { Modal Sendiri }} \times 100 \%
$$


Tabel 6. Matriks kriteria penetapan peringkat ROE

\begin{tabular}{lll}
\hline Peringkat & Keterangan & Kriteria \\
\hline 1 & Sangat sehat & Perolehan laba sangat sehat (rasio di atas 20\%). \\
\hline 3 & Sehat & $\begin{array}{l}\text { Perolehan laba tinggi (rasio ROE berkisar antara 12,51\% sampai dengan } \\
20 \%) .\end{array}$ \\
\hline 4 & Cukup sehat & $\begin{array}{l}\text { Perolehan laba cukup tinggi (rasio ROE berkisar antara 5,01\% sampai } \\
\text { dengan 12,5\%). }\end{array}$ \\
\hline 5 & Kurang sehat & $\begin{array}{l}\text { Perolehan laba rendah atau cenderung mengalami kerugian (ROE } \\
\text { mengarah negatif rasio berkisar antara 0\% sampai dengan 5\%). }\end{array}$ \\
\hline
\end{tabular}

Sumber : SE BI No.13/24/DPNP tahun 2011

c. Biaya operasional terhadap Pendapatan Operasional (BOPO)

Menurut Dendawijaya Biaya Operasional Pendapatan Operasional adalah rasio perbandingan antara biaya operasional dan pendapatan operasional. Rasio biaya operasional digunakan untuk mengukur tingkat efisiensi dan kemampuan bank dalam melakukan kegiatan operasi. Semakin rendah persentase BOPO maka semakin efisien bank dalam mengendalikan biaya operasionalnya, dengan adanya efisiensi biaya maka keuntungan yang diperoleh bank akan semakin besar dan sebaliknya semakin tinggi persentase BOPO maka menunjukkan kurangnya kemampuan bank dalam menekan biaya operasional dan dapat menimbulkan kerugian bank. Secara matematis BOPO dapat dirumuskan sebagi berikut:

$B O P O=\frac{\text { Beban Operasional }}{\text { Pendapatan Operasional }} \times 100 \%$

Tabel 7. Matriks kriteria penetapan peringkat BOPO

\begin{tabular}{lll}
\hline Peringkat & Keterangan & \multicolumn{1}{c}{ Kriteria } \\
\hline 1 & Sangat sehat & Tingkat efisiensi sangat baik (rasio BOPO kurang dari 83\%) \\
\hline 3 & Sehat & $\begin{array}{l}\text { Tingkat efisiensi baik (rasio BOPO berkisar antara 83\% samapai dengan } \\
85 \% \text { ) }\end{array}$ \\
\hline 4 & Cukup sehat & $\begin{array}{l}\text { Tingkat efisiensi cukup baik (rasio BOPO berkisar antara 85\% samapai } \\
\text { dengan 87\%) }\end{array}$ \\
\hline 5 & Kurang sehat & $\begin{array}{l}\text { Tingkat efisiensi cukup baik (rasio BOPO berkisar antara 87\% samapai } \\
\text { dengan 89\%) }\end{array}$ \\
\hline
\end{tabular}

Sumber : SE BI No.13/24/DPNP tahun 2011

d. Capital (Permodalan)

Capital Adequacy Ratio (CAR) rasio yang digunakan untuk mengukur kecukupan modal yang dimiliki bank yang megandung atau menghasilkan risiko, misalnya kredit atau pembiayaan yang diberikan. Semakin tinggi rasio CAR yang diperoleh oleh bank maka semakin bagus kualitas permodalan bank tersebut, begitupun sebaliknya.

$C A R=\frac{\text { Modal }}{\text { Aktiva Tertimbang Menurut Risiko }} \times 100 \%$ 
Tabel 8. Matriks kriteria penetapan peringkat CAR

\begin{tabular}{lll}
\hline Peringkat & Keterangan & Kriteria \\
\hline 1 & Sangat sehat & $\geq 12 \%$ \\
\hline 2 & Sehat & $9 \%-12 \%$ \\
\hline 3 & Cukup sehat & $8 \%-9 \%$ \\
\hline 4 & Kurang sehat & $6 \%-8 \%$ \\
\hline 5 & Tidak sehat & $\leq 6 \%$ \\
\hline
\end{tabular}

Sumber : SE BI No.13/24/DPNP tahun 2011

\section{Metode Penelitian}

Penelitian ini merupakan penelitian deskriptif yaitu suatu metode penelitian yang ditujukan untuk menggambarkan fenomena-fenomena yang berlangsung saat ini atau pada saat lampau. Penelitian ini akan dilakukan dengan mengumpulkan data-data sesuai dengan ketentuan yang telah diatur dalam Peraturan Bank Indonesia No. 13/1/PBI/2011 dan SE No. 13/ 24/ DPNP. Subjek penelitian dalam penelitian ini adalah PT Bank Muamalat Indonesia,Tbk. Objek penelitian ini adalah laporan keuangan dan tata kelolah publikasi PT Bank Muamalat Indonesia,Tbk Periode 2015-2017. Teknik pengumpulan data pada penelitian ini yaitu teknik dokumentasi dimana pengambilan data yang diperoleh melalui dokumendokumen. Data ini berupa laporan keuangan dan tata kelolah Bank Muamalat Indonesia periode 2015-2017.

Teknik yang digunakan adalah analisis laporan keuangan dengan menggunakan metode RGEC. Data yang diperoleh dalam penelitian ini dikumpulkan kemudian diolah dengan rumus yang sesuai dengan definisi operasional variabel. Langkah- langkah yang digunakan adalah sebagai berikut :

1. Mengumpulkan data-data dari laporan keuangan perusahaan berkaitan dengan variabel penelitian.

2. Melakukan pemeringkatan masing- masing analisis NPF, FDR, GCG, ROA, ROE, BOPO dan CAR.

3. Menetapkan peringkat komposit penilaian tingkat kesehatan bank dari tahun 2015 sampai tahun 2017. Nilai komposit untuk rasio keuangan masing- masing komponen yang menempati peringkat komposit akan bernilai sebagai berikut :

a. Peringkat $1=$ setiap kali ceklist dikalikan 5

b. Peringkat $2=$ setiap kali ceklist dikalikan 4

c. Peringkat $3=$ setiap kali ceklist dikalikan 3

d. Peringkat $2=$ setiap kali ceklist dikalikan 2

e. Peringkat $1=$ setiap kali ceklist dikalikan 1

Nilai komposit yang telah diperoleh dari mengalikan tiap ceklist kemudian ditentukan bobot kriteria tingkat kesehatan bank dengan metode RGEC.

Tabel 9. Bobot Kriteria Tingkat Kesehatan Bank Dengan Metode RGEC

\begin{tabular}{lll}
\hline Bobot & Peringkat komposit & Keterangan \\
\hline $86 \%-100 \%$ & Peringkat komposit 1 & Sangat sehat \\
\hline $71 \%-85 \%$ & Peringkat komposit 2 & Sehat \\
\hline $61 \%-70 \%$ & Peringkat komposit 3 & Cukup sehat \\
\hline $41 \%-60 \%$ & Peringkat komposit 4 & Kurang sehat \\
\hline$\leq 40 \%$ & Peringkat komposit 5 & Tidak sehat \\
\hline
\end{tabular}

Sumber : Bank Indonesia 


$$
\text { Peringkat komposit }=\frac{\text { jumlah nilai komposit }}{\text { total nilai komposit keseluruhan }} \times 100 \%
$$

4. Menarik kesimpulan terhadap tingkat kesehatan bank sesuai dengan standar perhitungan kesehatan bank yang telah ditentukan oleh Bank Indonesia berdasarkan perhitungan analisis rasio masing- masing variabel.

\section{Hasil Penelitian dan Pembahasan}

Tabel 10. Penilaian Tingkat Kesehatan PT.Bank Muamalat Indonesia,Tbk Tahun 2015

\begin{tabular}{|c|c|c|c|c|c|c|c|c|}
\hline \multirow[t]{2}{*}{ Tahun } & \multirow[t]{2}{*}{ Komponen } & \multirow[t]{2}{*}{ Rasio } & \multirow[t]{2}{*}{ Rasio \% } & \multicolumn{3}{|c|}{ Peringkat } & \multirow[t]{2}{*}{ Kriteria } & \multirow[t]{2}{*}{ Komposit } \\
\hline & & & & 123 & 4 & 5 & & \\
\hline \multirow[t]{7}{*}{2015} & Profile & NPF & 7,11 & $\sqrt{1}$ & $T$ & & Cukup sehat & \multirow{7}{*}{$\begin{array}{l}\text { KURANG } \\
\text { SEHAT }\end{array}$} \\
\hline & Risiko & FDR & 90,30 & $\sqrt{1}$ & $T$ & & Cukup sehat & \\
\hline & $G C G$ & & & $\sqrt{1}$ & 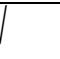 & & Cukup sehat & \\
\hline & \multirow[t]{3}{*}{ Earnings } & ROA & 0,20 & & $\sqrt{ }$ & & Kurang sehat & \\
\hline & & ROE & 2,78 & & $\sqrt{ }$ & & Kurang sehat & \\
\hline & & BOPO & 97,36 & & & $\sqrt{ }$ & Tidak sehat & \\
\hline & Capital & CAR & 12 & $\sqrt{ }$ & & & Sehat & \\
\hline \multicolumn{2}{|c|}{ Nilai Komposit } & & & $\begin{array}{lll}0 & 4 & 9\end{array}$ & 4 & 1 & $18: 35 \times 100 \%$ & $=51,43 \%$ \\
\hline
\end{tabular}

Dari hasil keseluruhan pada Tabel 10 dapat disimpulkan bahwa Tingkat Kesehatan PT. Bank Muamalat Indonesia selama tahun 2015 memperoleh predikat "Kurang Sehat" dengan peringkat komposit akhir 4 sebab dari perhitungan nilai komposit akhir diperoleh nilai sebesar $51,43 \%$ atau $41 \% \leq \mathrm{PK}<60 \%$. Dengan beberapa indikator variabel sebagai berikut:

1. NPF sebesar $7,11 \%$ yang berarti terdapat $7,11 \%$ dana yang termasuk dalam pembiayaan kurang lancar, diragukan dan macet dari total pembiayaan yang diberikan oleh bank. Sesuai dengan matriks penetapan nilai komposit yang ada pada surat edaran Bank Indonesia, dengan memiliki NPF sebesar 7,11\% maka PT. Bank Muamalat Indonesia termasuk dalam komposit peringkat 3 yaitu cukup sehat karena $5 \% \leq \mathrm{NPF}<8 \%$.

2. FDR (financing to debt ratio) sebesar $90,30 \%$ yang berarti setiap dana yang dihimpun bank dapat mendukung pinjaman yang diberikan sebesar $90,30 \%$ dari total pembiayaan yang diberikan. Hal ini menunjukkan bahwa bank dapat mengelolah simpanan dalam bentuk pembiayaan sebesar $90,30 \%$ dari total pembiayaan yang diberikan. Hal ini menunjukkan bahwa bank dapat mengelolah simpanan dalam bentuk pembiayaan sebesar 90,30\%. Sesuai dengan matriks penetapan nilai komposit yang ada disurat edaran Bank Indonesia, PT.Bank Muamalat Indonesia dengan memiliki nilai FDR sebesar 90,30\% maka termasuk dalam tingkat komposit 3 yaitu cukup sehat karena melebihi dari $85 \%$ dan kurang dari $100 \%$. Dalam hal ini PT. bank Muamalat Indonesia menunjukkan indikasi rendahnya likuditas bank.

3. Good Corporate Governance PT.Bank Muamalat Indonesia pada tahun 2015 memperoleh predikat cukup sehat berdasarkan hasil Self Assessment PT. Bank Muamalat Indonesia yang diperoleh dari Laporan tata kelolah perusahaan. Hal tersebut Mencerminkan Manajemen Bank telah melakukan penerapan Good Corporate Governance yang secara umum cukup baik. Hal ini tercermin dari penerapan atas prinsip-prinsip Good Corporate Governance yang cukup memadai. Apabila terdapat kelemahan dalam penerapan prinsip Good 
Corporate Governance maka secara umum kelemahan tersebut cukup signifikan dan memerlukan perhatian yang cukup dari manajemen Bank.

4. Pada tahun 2015 diperoleh ROA (Return On Asset) sebesar 0,20\%, berarti tingkat produktivitas aset dari rata-rata total aset yang digunakan menghasilkan laba sebesar 0,20\%. sesuai dengan matriks penetapan nilai komposit yang ada di surat edaran Bank Indonesia, PT.Bank Muamalat Indonesia memiliki ROA sebesar 0,20\% dengan tingkat komposit 4 yaitu predikat kurang sehat karena kurang dari $0,5 \%$.

5. Pada tahun 2015 diperoleh ROE (Return On Equity) sebesar 2,78\%, berarti terdapat 2,78\% laba bersih yang diperoleh dari modal sendiri yang ditanamkan di bank. Dalam hal ini sesuai dengan matriks penetapan nilai komposit yang ada di surat edaran Bank Indonesia, PT.Bank Muamalat Indonesia memiliki ROE sebesar 2,78\% dengan tingkat komposit 4 kurang sehat karena persentase kurang dari $5 \%$ yang berarti perolehan laba rendah atau cenderung mengalami kerugian.

6. Diperoleh BOPO (Beban Operasional terhadap Pendapatan Operasional) sebesar 97,36\%, berarti terdapat $97,36 \%$ biaya operasional yang digunakan untuk kegiatan operasional bank. Dalam hal ini sesuai dengan matriks penetapan nilai komposit yang ada di surat edaran Bank Indonesia, PT.Bank Muamalat Indonesia memiliki BOPO sebesar 97,36\% dengan tingkat komposit 5 tidak sehat karena rasio diatas $89 \%$ yang berarti bank memiliki tingkat efisiensi sangat buruk dalam menjalankan operasi dalam hal ini biaya tidak terkontrol yang pada akhirnya menyebabkan pendapatan menurun hingga berujung pada menurunnya kualitas pembiayaan karena kurangnya pendapatan untuk menutupi kegiatan operasional penyaluran pembiayaan.

Dari hasil perhitungan CAR (Capital Adequacy Ratio) PT. Bank Muamalat Indonesia tahun 2015 maka Capital atau permodalan diperoleh sebesar 12\% dengan memperoleh predikat sehat, dalam arti kecukupan modal yang dimiliki Bank Muamalat Indonesia untuk menunjang aktiva yang mengandung atau menghasilkan risiko dalam hal ini berupa pemberian pembiayaan sebesar $12 \%$. Dalam hal ini sesuai dengan matriks penetapan nilai komposit yang ada di surat edaran Bank Indonesia, PT.Bank Muamalat Indonesia memiliki CAR sebesar 12\% dengan tingkat komposit 2 predikat sehat karena rasio sama dengan $12 \%$ yang berarti bank dengan baik dapat memenuhi kecukupan modalnya.

Tabel 11. Penilaian Tingkat Kesehatan PT.Bank Muamalat Indonesia,Tbk Tahun 2016

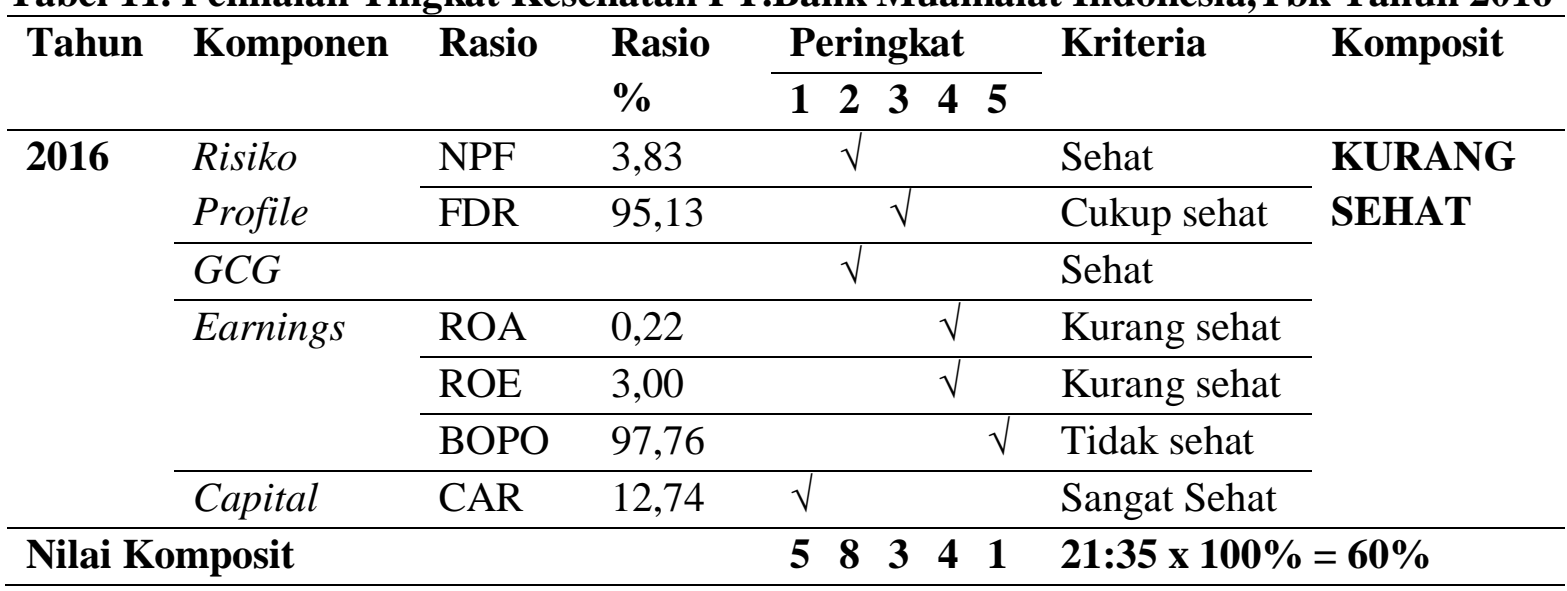


Dari hasil keseluruhan di atas dapat disimpulkan bahwa Tingkat Kesehatan PT. Bank Muamalat Indonesia selama tahun 2016 memperoleh predikat "Kurang Sehat" dengan peringkat komposit akhir 4 sebab dari perhitungan nilai komposit akhir diperoleh nilai sebesar $60 \%$ atau $41 \% \leq \mathrm{PK}<60 \%$. Hal ini menunjukkan bahwa tingkat kesehatan bank dari tahun 2015 ke tahun 2016 tidak mengalami perubahan, masih tetap memperoleh predikat kurang sehat. Dengan beberapa indikator variabel sebagai berikut :

1. Pada tahun 2016 PT. Bank Muamalat indonesia memperoleh NPF sebesar 3,83\%. Dibandingkan tahun 2015, nilai rasio NPF untuk tahun 2016 mengalami penurunan sebesar $3,28 \%$, yang berarti tahun 2016 telah berkurangnya jumlah pembiayaan bermasalah yg terjadi. Sesuai dengan matriks penetapan nilai komposit yang ada pada surat edaran Bank Indonesia, dengan memiliki NPF sebesar 3,83\% maka PT. Bank Muamalat Indonesia termasuk dalam komposit peringkat 2 dengan predikat sehat karena $2 \% \leq \mathrm{NPF}<5 \%$.

2. Pada tahun 2016 PT. Bank Muamalat indonesia memperoleh FDR (financing to debt ratio) sebesar 95,13\%. Dibandingkan tahun 2015, nilai rasio FDR untuk tahun 2016 semakin meningkat sebesar $4,83 \%$ yang berarti semakin tinggi rasio FDR memberikan indikasi rendahnya likuiditas bank, karena dana bank lebih banyak digunakan untuk memberikan pembiayaan dari pada diinvestasikan dalam bentuk kas. Sehingga kemampuan suatu bank dalam menghasilkan laba akan meningkat seiring peningkatan pemberian pembiayaan. Sesuai dengan matriks penetapan nilai komposit yang ada disurat edaran Bank Indonesia, PT.Bank Muamalat Indonesia dengan memiliki nilai FDR sebesar 95,13\% maka termasuk dalam tingkat komposit 3 dengan predikat cukup sehat karena $85 \% \leq \mathrm{FDR}<100 \%$.

3. Good Corporate Governance PT.Bank Muamalat Indonesia pada tahun 2016 memperoleh predikat sehat berdasarkan hasil Self Assessment PT. Bank Muamalat Indonesia yang diperoleh dari Laporan tata kelolah perusahaan. Hal ini mencerminkan Manajemen Bank telah melakukan penerapan Good Corporate Governance yang secara umum baik. Hal ini tercermin dari penerapan atas prinsip-prinsip Good Corporate Governance yang memadai. Apabila terdapat kelemahan dalam penerapan prinsip Good Corporate Governance maka secara umum kelemahan tersebut kurang signifikan dan dapat terselesaikan dengan tindakan normal oleh manajemen bank.

4. Pada tahun 2016 diperoleh ROA (Return On Asset) sebesar 0,22\%. Hasil pengukuran rasio ROA dari tahun 2015 ke tahun 2016 mengalami kenaikan sebesar 2\%, yang berarti tingkat produktivitas dan laba juga ikut meningkat. Sesuai dengan matriks penetapan nilai komposit yang ada di surat edaran Bank Indonesia, PT.Bank Muamalat Indonesia memiliki ROA sebesar $0,22 \%$ dengan tingkat komposit 4 dengan predikat kurang sehat karena $0 \% \leq \mathrm{ROA}<$ $0,5 \%$

5. Pada tahun 2016 diperoleh ROE (Return On Equity) sebesar 3\%. Hasil perhitungan rasio ROE dari tahun 2015 ke tahun 2016 mengalami kenaikan sebesar 2\%, yang berarti tahun 2016 telah terjadi kenaikan laba bersih yang diperoleh dari modal sendiri yang ditanamkan di bank. Dalam hal ini sesuai dengan matriks penetapan nilai komposit yang ada di surat edaran Bank Indonesia, PT.Bank Muamalat Indonesia memiliki ROE sebesar 3,00\% dengan tingkat komposit 4 kurang sehat karena persentase $0 \% \leq \mathrm{ROE}<5 \%$ yang berarti perolehan laba rendah atau cenderung mengalami kerugian.

6. Diperoleh BOPO (Beban Operasional terhadap Pendapatan Operasional) sebesar 97,76\%, Hasil perhitungan rasio BOPO dari tahun 2015 ke tahun 2016 mengalami kenaikan sebesar $0,4 \%$. Hal ini berarti menunjukkan kurangnya kemampuan bank dalam menekan biaya operasional dan meningkatkan pendapatan operasionalnya sehingga dapat menimbulkan kerugian bank. Dalam hal ini sesuai dengan matriks penetapan nilai komposit yang ada di 
surat edaran Bank Indonesia, PT.Bank Muamalat Indonesia memiliki BOPO sebesar 97,76\% dengan tingkat komposit 5 dengan predikat tidak sehat karena rasio diatas $89 \%$

Dari hasil perhitungan CAR (Capital Adequacy Ratio) PT. Bank Muamalat Indonesia tahun 2016 maka Capital atau permodalan diperoleh sebesar 12,74\%, Hasil perhitungan CAR dari tahun 2015 ke tahun 2016 mengalami peningkatan sebesar 0,74\% yang berarti bank dapat memenuhi kecukupan modalnya dengan lebih baik lagi. Dalam hal ini sesuai dengan matriks penetapan nilai komposit yang ada di surat edaran Bank Indonesia, PT.Bank Muamalat Indonesia memiliki CAR sebesar $12,74 \%$ dengan tingkat komposit 1 predikat sangat sehat karena rasio lebih dari $12 \%$.

Tabel 12. Penilaian Tingkat Kesehatan PT.Bank Muamalat Indonesia,Tbk Tahun 2017

\begin{tabular}{|c|c|c|c|c|c|c|}
\hline \multirow[t]{2}{*}{ Tahun } & \multirow[t]{2}{*}{ Komponen } & \multirow[t]{2}{*}{ Rasio } & \multirow{2}{*}{$\begin{array}{l}\text { Rasio } \\
\%\end{array}$} & Peringkat & \multirow[t]{2}{*}{ Kriteria } & \multirow[t]{2}{*}{ Komposit } \\
\hline & & & & $\begin{array}{lllll}1 & 2 & 3 & 4 & 5\end{array}$ & & \\
\hline \multirow[t]{7}{*}{2017} & Profile & NPF & 4,43 & $\sqrt{ }$ & Sehat & \multirow{7}{*}{$\begin{array}{l}\text { KURANG } \\
\text { SEHAT }\end{array}$} \\
\hline & Risiko & FDR & 84,41 & $\sqrt{ }$ & Sehat & \\
\hline & $G C G$ & & & $\sqrt{ }$ & cukup Sehat & \\
\hline & Earnings & ROA & 0,11 & $\sqrt{ }$ & kurang sehat & \\
\hline & & ROE & 0,87 & $\sqrt{ }$ & Kurang sehat & \\
\hline & & BOPO & 97,68 & $\sqrt{ }$ & Tidak sehat & \\
\hline & Capital & CAR & 13,62 & $\sqrt{ }$ & Sangat Sehat & \\
\hline
\end{tabular}

Dari hasil keseluruhan di atas dapat disimpulkan bahwa Tingkat Kesehatan PT. Bank Muamalat Indonesia selama tahun 2017 memperoleh predikat "Kurang Sehat" dengan peringkat komposit akhir 4 sebab dari perhitungan nilai komposit akhir diperoleh nilai sebesar $60 \%$ atau $41 \% \leq \mathrm{PK}<60 \%$. Hal ini menunjukkan bahwa tingkat kesehatan bank dari tahun 2015 -2017 tidak mengalami perubahan, masih tetap memperoleh predikat kurang sehat.

1. Pada tahun 2017 PT. Bank Muamalat indonesia memperoleh NPF sebesar 4,43\%. Rasio NPF meningkat sebesar 0,6\% dari tahun 2016 sebesar 3,83\% menjadi 4,43\% pada tahun 2017 . Hal ini berarti tahun 2017 telah terjadi peningkatan jumlah pembiayaan bermasalah dibandingkan dengan tahun sebelumnya. Sesuai dengan matriks penetapan nilai komposit yang ada pada surat edaran Bank Indonesia, dengan memiliki NPF sebesar 4,43\%\% maka PT. Bank Muamalat Indonesia termasuk dalam komposit peringkat 2 dengan predikat sehat karena $2 \% \leq \mathrm{NPF}<5 \%$.

2. Pada tahun 2017 PT. Bank Muamalat indonesia memperoleh FDR (financing to debt ratio) sebesar 84,41\%. Rasio FDR menurun sebesar 10,72\% dari tahun 2016 sebesar 95,13\% menjadi 84,41\% pada tahun 2017. Dengan terjadinya penurunan FDR di tahun 2017 memberikan indikasi tingginya likuiditas bank. Berkurangnya dana bank yang digunakan untuk memberikan pembiayaan, karena dana bank lebih sedikit digunakan untuk memberikan pembiayaan maka kemampuan bank dalam menghasilkan laba akan menurun seiring penurunan pemberian pembiayaan. Sesuai dengan matriks penetapan nilai komposit yang ada disurat edaran Bank Indonesia, PT.Bank Muamalat Indonesia dengan memiliki nilai FDR sebesar $84,41 \%$ maka termasuk dalam tingkat komposit 2 dengan predikat sehat karena $75 \% \leq \mathrm{FDR}<85 \%$. 
3. Good Corporate Governance (GCG) Bank Muamalat Indonesia di tahun 2017 telah dijalankan secara komprehensif dengan hasil peringkat self assessment GCG Bank Muamalat secara Individual adalah 3 (tiga) dengan definisi peringkat yang mencerminkan Manajemen Bank telah melakukan penerapan Good Corporate Governance yang secara umum cukup sehat. Hal ini tercermin dari penerapan atas prinsip-prinsip Good Corporate Governance yang cukup memadai. Apabila terdapat kelemahan dalam penerapan prinsip Good Corporate Governance maka secara umum kelemahan tersebut cukup signifikan dan memerlukan perhatian yang cukup dari manajemen Bank.

4. Pada tahun 2017 diperoleh ROA (Return On Asset) sebesar 0,11\%, Rasio ROA menurun sebesar $0,11 \%$ dari tahun 2016 sebesar $0,22 \%$ menjadi $0,11 \%$ pada tahun 2017 yang berarti tingkat produktivitas dan laba juga ikut menurun. Sesuai dengan matriks penetapan nilai komposit yang ada di surat edaran Bank Indonesia, PT.Bank Muamalat Indonesia memiliki ROA sebesar $0,11 \%$ dengan tingkat komposit 4 dengan predikat kurang sehat karena $0 \%$ $\leq \mathrm{ROA}<0,5 \%$.

5. Pada tahun 2017 diperoleh ROE (Return On Equity) sebesar 0,87\%. Rasio ROE menurun sebesar 2,13\% dari tahun 2016 sebesar 3,00\% menjadi 0,87\% pada tahun 2017, yang berarti tahun 2017 telah terjadi penurunan laba bersih yang diperoleh dari modal sendiri yang ditanamkan di bank. Dalam hal ini sesuai dengan matriks penetapan nilai komposit yang ada di surat edaran Bank Indonesia, PT.Bank Muamalat Indonesia memiliki ROE sebesar 0,87\% dengan tingkat komposit 4 kurang sehat karena persentase $0 \% \leq \mathrm{ROE}<5 \%$ yang berarti perolehan laba rendah atau cenderung mengalami kerugian.

6. Pada tahun 2017 diperoleh BOPO (Beban Operasional terhadap Pendapatan Operasional) sebesar 97,68\%. Hasil perhitungan rasio BOPO dari tahun 2015 ke tahun 2016 mengalami penurunan sebesar $0,08 \%$. Hal ini berarti tahun 2017 bank mampu mengurangi atau menekan biaya operasional dari tahun sebelumnya sehingga dapat meminimalkan timbulnya kerugian bank. Dalam hal ini sesuai dengan matriks penetapan nilai komposit yang ada di surat edaran Bank Indonesia, PT.Bank Muamalat Indonesia memiliki BOPO sebesar 97,68\% dengan tingkat komposit 5 dengan predikat tidak sehat karena rasio diatas $89 \%$.

Dari hasil perhitungan CAR (Capital Adequacy Ratio) PT. Bank Muamalat Indonesia tahun 2017 maka Capital atau permodalan diperoleh sebesar 13,62\%. Hasil perhitungan CAR dari tahun 2016 ke tahun 2017 mengalami peningkatan sebesar 0,88\% yang berarti terdapat peningkatan dalam memenuhi kecukupan modal bank dengan lebih baik lagi. Dalam hal ini sesuai dengan matriks penetapan nilai komposit yang ada di surat edaran Bank Indonesia, PT.Bank Muamalat Indonesia memiliki CAR sebesar 13,62\% dengan tingkat komposit 1 predikat sangat sehat karena rasio lebih dari $12 \%$.

\section{Kesimpulan}

Berdasarkan pembahasan pada latar belakang, kajian pustaka, metode penelitian, dan hasil penelitian maka diambil kesimpulan bahwa Penilaian tingkat kesehatan PT. Bank Muamalat Indonesia,Tbk pada tahun 2015 sampai dengan 2017 yang diukur dengan pendekatan RGEC (Risk Profile, Good Corporate Governance, Earnings, Capital) secara keseluruhan dapat dikatakan bahwa PT. Bank Muamalat Indonesia,Tbk peringkat Komposit 4 (PK-4), mencerminkan kondisi bank yang secara umum "KURANG SEHAT", sehingga dinilai kurang mampu menghadapi pengaruh negatif yang signifikan dari perubahan kondisi bisnis dan faktor eksternal lainnya.

Pada penelitian ini terdapat beberapa keterbatasan penelitian baik terkait keterbatasan teknis maupun keterbatasan dalam pengembangan alur penelitian, dari keterbatasan yang ada 
selanjutnya disertakan pula masukan untuk penelitian mendatang, Yaitu : 1)Data keuangan perbankan yang dijadikan sebagai indikator penilaian tingkat kesehatan bank tidak sepenuhnya tercantum dalam laporan keuangan yang dipublikasikan bank,sehingga ada beberapa indikator yang belum dapat dinilai antara lain faktor risiko pasar,risiko operasional, risiko hukum, risiko stratejik, risiko kepatuhan, dan risiko reputasi. 2). Dalam faktor risk profile tidak semua indikator dinilai hanya risiko pembiayaan/ kredit dan risiko likuiditas saja yang dinilai karena keterbatasan informasi yang didapat pada bank yang diteliti. 3). Peneliti selanjutnya disarankan untuk memperluas cakupan penelitian tentang penilaian kesehatan bank dengan menghitung 8 indikator profil risiko antara lain; risiko kredit, risiko likuitas, risiko pasar, risiko operasional, risiko hukum, risiko stratejik, risiko kepatuhan, dan risiko reputasi. 4). Peneliti selanjutnya diharapkan menambah periode tahun penelitian sesuai dengan tahun pergantian dan objek penelitian. Penambahan tahun dan objek penelitian berpotensi akan memberikan hasil yang lebih baik.

\section{DAFTAR PUSTAKA}

Artyka, N. 2015. Penilaian Kesehatan Bank Dengan Metode RGEC pada PT. Bank Rakyat Indonesia (PERSERO) Tbk Periode 2011-2013. Skripsi . Universitas Negeri Yogyakarta. Yogyakarta.

Astutik, P. 2014. Pengaruh tingkat kesehatan bank menurut Risk Based Bank Rating terhadap kinerja keuangan (studi pada bank Umum Syariah di Indonesia). Jurnal fakultas ekonomi dan bisnis . Universitas Brawijaya

Bambang Rianto Rustam. 2013. Manjemen Risiko Perbankan Syariah di Indonesia. Salemba. Jakarta Selatan.

Bank Indonesia, Lampiran Surat Edaran No.9/24/2007 Tentang Penilaian Kesehatan Bank Umum Berdasarkan Prinsip Syariah.

Calista, A. 2013. Analisis Perbandingan Kinerja Keuangan PT. Bank Syariah Mandiri dan PT. Bank Muamalat Indonesia dengan Metode RGEC (Risk Profile, Good Corporate Governance, Earnings, dan Capital) tahun 2012. Skripsi tidak diterbitkan.

Gemala Dewi. 2006. Aspek-aspek Hukum dalam Perbankan dan Peransuransian Syariah. Jakarta: Kencana Prenada Media Group.

Heidy Arrvida Lasta, Zainul Arifin, dan Nila Firdausi Nuzula. (2014). Analisis Tingkat Kesehatan Bank Dengan Menggunakan Pendekatan RGEC (Risk Profile, Good Corporate Governance, Earnings, Capital) (Studi pada PT Bank Rakyat Indonesia Tbk Periode 2011-2013). Jurnal Administrasi Bisnis. Vol. 13 No. 2 Agustus 2014. Universitas Brawijaya.

Ikatan Bankir Indonesia (IBI).2015. Manajemen Risiko .PT Gramedia Pustaka Utama. Jakarta Pusat.

Kasmir.2012. Manajemen Perbankan. PT. Raja Grafindo Persada. Jakarta.

Kasmir.,S.E,.M.M. 2008. Bank dan Lembaga Keuangan Lainnya. PT. Raja Grafindo Persada. Jakarta.

Khaerul Umam. 2013. Manajemen Perbankan Syariah .Pustaka Setia. Bandung.

Khisti Minarrohmah, Fransisca Yaningwati, dan Nila Firdausi Nuzula. (2014). Analisis Tingkat Kesehatan Bank Dengan Menggunkan Pendekatan RGEC (Risk profile, Earnings, Good Corporate Governance, dan Capital) (Studi pada PT. Bank Central Asia, Tbk Periode 2010-2012). Jurnal Administrasi Bisnis. Vol. 17 No. 1 Desember 2014. Universitas Brawijaya. 
Marwanto. 2014. Analisis Komparatif Tingkat Kesehatan Bank Umum Syariah dan Bank Umum Konvensional dengan Menggunakan Metode Risk Profile, Good Corporate Governance, Earnings, dan Capital (RGEC). Jurnal. Universitas Lampung. Lampung.

Peraturan Bank Indonesia. 2011. Peraturan Bank Indonesia No. 13/PBI/2011, tentang tata cara penilaian kesehatan bank umum.

Peraturan Bank Indonsia No.8/4/PBI/2006. Tentang Pelaksanaan Good Corporate Governance Bagi Bank Umum.

Ramlan Ginting et al. 2012. Kodifikasi Peraturan Bank Indonesia tentang Penilaian Tingkat Kesehatan Bank Umum .Bank Indonesia. Jakarta.

Surat Edaran Bank Indonesia No. 6/23/DPNP Perihal: Sistem Penilaian Tingkat

Kesehatan Bank Umum. Jakarta: Bank Indonesia.

Surat Edaran Bank Indonesia. (2011). Surat Edaran Bank Indonesia No.13/24/DPNP tanggal 25 Oktober 2011, tentang Matriks Perhitungan Analisis Komponen Faktor Analisis RGEC untuk Bank Umum.

Ulya, Nadia Iffatul. 2014. Analisis Perbandingan Tingkat Kesehatan Bank Syariah dan Konvensional Berdasarkan Risk Profile, Good Corporate Governance, Earnings,dan Capital. Skripsi . UIN Sunan Kalijaga. Yogyakarta.

Undang-undang. (1998). Undang-undang No. 10 Tahun 1998, tentang Perbankan.

Veithzal Rivai dan Rifki Ismal. 2013. Islamic Risk Management For Islamic Bank. Gramedia Pustaka Utama. Jakarta.

Veranda Aga Refmasari. (2013). Penilaian Tingkat Kesehatan Bank Umum menggunakan Metode RGEC Dengan Cakupan Risk Profile, Earnings, dan Capital pada Bank Pembangunan Daerah Provinsi Daerah Istimewa Yogyakarta tahun 2012. Skripsi. Universitas Negeri Yogyakarta.

http://www.bankmuamalat.co.id/hubungan-investor/laporan-tahunan. Diakses (10 Juli 2018) Pukul 23.22 Wita.

http://www.bankmuamalat.co.id/hubungan-investor/laporan-gcg. Diakses (16 Juli 2018) Pukul 2.42 PM Wita.

https://www.cnnindonesia.com/ekonomi/20180228173307-78-279466/ketua-mui-bankmuamalat-boleh-sakit-tapi-tak-boleh-mati?. Diakses (31 Mei 2018) Pukul 23.17 WITA.

https://ekbis.sindonews.com/read/1246349/178/tepis-hoax-bank-muamalat-tegaskanperbankan-syariah-nasional-1507386131. Diakses (31 Mei 2018) Pukul 23.17 WITA. 